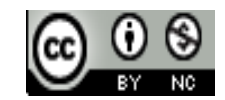

Jurnal Bimbingan Konseling Indonesia is licensed under

A Creative Commons Attribution-Non Commercial 4.0 International License.

\title{
ANALISIS KINERJA KOMPETENSI PRIBADI DOSEN PROGRAM STUDI BIMBINGAN DAN KONSELING FKIP ULM
}

\author{
Sulistiyana $^{1)}$, Muhammad Andri Setiawan ${ }^{2)}$, Maretha Dwi Yani ${ }^{3)}$ \\ ${ }^{1)}$ Fakultas Keguruan dan Ilmu Pendidikan; Universitas Lambung Mangkurat, Banjarmasin, Indonesia \\ E-mail:sulis.bk@ulm.ac.id \\ ${ }^{2)}$ Fakultas Keguruan dan Ilmu Pendidikan; Universitas Lambung Mangkurat, Banjarmasin, Indonesia \\ E-mail: andri.bk@ulm.ac.id \\ ${ }^{3)}$ Fakultas Keguruan dan Ilmu Pendidikan; Universitas Lambung Mangkurat, Banjarmasin, Indonesia \\ E-mail: marethaaini@gmail.com
}

\begin{abstract}
Abstrak. Kompetensi Dosen terdiri dari kompetensi pedagogik, profesional, sosial dan kepribadian. Penilaian keempat kompetensi tersebut dilakukan dengan mendeskripsikan persepsi dari atasan, sejawat, mahasiswa dan diri sendiri. Penelitian ini bertujuan mendeskripsikan kinerja dosen Program Studi Bimbingan dan Konseling berdasarkan kompetensi kepribadian, dengan responden mahasiswa aktif. Secara metodologis, penelitian ini didasarkan pada penelitian analisis deskriptif metode survei sesuai dengan tujuan penelitian yaitu menganalisis kinerja dosen kompetensi pribadi dosen. Adapun jumlah dosen tetap yang dinilai ada 9 orang dan sebagai responden terdapat 346 orang mahasiswa aktif dari rentang angkatan 2012-2018. Hasil penelitian menunjukkan menjadi contoh dalam bersikap berperilaku menempati peringkat utama disusul dengan kewibawaan sebagai pribadi dan terakhir adil dalam memperlakukan mahasiswa. Meskipun tingkat pilihan yang berarti sangat rendah tidak besar, tetap saja perlu mendapat perhatian bersama yakni terutama pada poin kearifan dalam mengambil keputusan. Disarankan agar pimpinan fakultas dapat mengembangkan program yang bertajuk pada pengembangan pelatihana manajemen kepribadian.
\end{abstract}

Kata Kunci: Kinerja Kompetensi Dosen; Kompetensi Kepribadian; Mahasiswa; Program Studi Bimbingan dan Konseling

\section{Pendahuluan}

Dosen diartikan sebagai pendidik profesional dan ilmuwan yang berperan mentransformasikan dan mengembangkan ilmu pengetahuan, teknologi, dan seni melalui pendidikan, penelitian, dan pengabdian kepada masyarakat [1]. Menunjang perannya maka seorang dosen dipersyaratkan memiliki sejumlah kompetensi sebagai bukti unjuk kinerja dosen selama ia berkecimpung pada dunia perguruan tinggi [2]. Kemampuan profesional dosen terukur pada penilaian terhadap persepsi dari atasan, sejawat, mahasiswa dan diri sendiri [3].
Kemampuan krusial yang terlihat dalam kehidupan perguruan tinggi terlihat pada kemampuan dosen dalam bidang belajar-mengajar, karena dalam prosesnya akan terlihat secara utuh empat kompetensi yang dimaksud yang tertera pada kemampuan yang berkenaan dengan waktu, komunikasi, proses belajar-pembelajaran, dan evaluasi belajar [4].

Dari proses belajar-mengajar yang dimaksud maka, terdapat empat kompetensi bagi dosen [5] yakni kompetensi pedagogik, yaitu mengelola pembelajaran mahasiswa untuk mengaktualisasikan berbagai potensi yang dimilikinya. Penilaian oleh mahasiswa sebagai pengguna menjadi lebih efektif karena mahasiswa berada pada posisi sebagai pengguna, yang dilakukan stakeholders dan rekan sejawat lebih pada 
penilaian kompetensi yang bisa diukur berbeda dengan kompetensi kepribadian yang tidak bisa diukur dalam satuan yang terstruktur [6]. Kompetensi kepribadian, meliputi kriteria kepribadian stabil dan penuh keteladanan. Kompetensi sosial ditandai kemampuan berinteraksi secara efektif dan efisien. Kompetensi profesional berupa kemampuan menguasai materi dengan mendalam [7].

Keempat kompetensi dosen tersebut sifatnya berkembang dan sangat berkembang, karena bisa naik dan turun secara periodik. Pembinaan terus-menerus mutlak untuk dilakukakan perguruan tinggi [8]. Diantara empat kompetensi yang dimaksud maka kompetensi kepribadian merupakan kompentensi yang memegang peranan penting dalam pengembangan kinerja utuh dosen, [9] karena kepribadian menjadikan seorang pendidik dan pembina bagi mahasiswa. Secara umum hendaknya seorang pendidik menyadari akan peran yang dapat diambilnya untuk mencapai tujuan pendidikan karena secara umum akan berhubungan dengan persyaratan kepribadian. Seorang pendidik berperan menurunkan segala tingkah laku dan sikap bawaan pada saat mengajar yang akan memengaruhi anak didik. Hal ini bisa dimaknai sebagai bagian dari tugas pendidik yang berlandaskan pada kompetensi kepribadian [10]. Semua itu, perlu dan penting untuk diperhatikan oleh seorang guru jika tujuan pembinaan di sekolah atau madrasah dalam pembinaan anak didik tersebut ingin tercapai [11].

Baik guru ataupun dosen perlu menyadari bahwa aspek kepribadian berperan penting dalam membentuk unsur aspek motivasi yang lain yakni kualifikasi akademik, dan pengalaman mengajar [12]. Secara umum, antara kepentingan aspek ini juga terjadi pada guru [13]. Oleh karenanya, penilaian kinerja kompetensi dosen juga menuntut keselarasan rancang bangun sistem yang dibangun dan diinginkan [14]. Penilaian terhadap kompetensi kepribadian akan menunjukkan kinerja. Kompleksitas kompetensi kepribadian tidak dapat diukur karena indikatornya didominasi persepsi mahasiswa sebagai pengguna jasa pelayanan pendidikan. Secara umum, kinerja dinilai ataupun diawasi agar mampu mencapai tujuan organisasi. Kompetensi kepribadian sebagai kompetensi agak sulit untuk diukur bahkan hampir semua kompetensi apabila sudah berhubungan dengan persepsi mahasiswa [15].

Kompetensi kepribadian dan kompetensi sosial akan berpengaruh terhadap kinerja dosen. Terdapat sejumlah indikator yang dipandang membentuk kedua kompetensi [16] Penelitian pengaruh kompetensi pedagogik dan kompetensi kepribadian terhadap kinerja dosen mengungkapkan kompetensi pedagogik, kompetensi dan kepribadian terhadap kinerja dosen tergolong tinggi [17].

Berangkat dari gambaran di atas maka, peneliti bermaksud mengadakan penelitian tentang kinerja kompetensi pribadi dosen Program Studi Bimbingan dan Konseling FKIP Universitas Lambung Mangkurat.

\section{METODE}

Metode yang digunakan deskriptif studi survei (survey study). Subjek penelitian adalah mahasiswa aktif Program Studi Bimbingan dan Konseling dari angkatan 2012-2018 sebanyak 346 orang mahasiswa dengan teknik pengambilan sampel jenuh. Pengumpulan data dilakukan dengan teknis pengumpulan data menggunakan googleform yang diberikan kepada seluruh anggota populasi. Namun pada kenyataannya dari 346 orang mahasiswa yang ditargetkan hanya 236 orang responden mengisi, sisanya dengan jumlah 33 orang responden tidak mengisi. Dosen yang diukur kinerja kompetensi kepribadiannya ada 9 orang dosen.

Pada desain instrumen yang digunakan merupakan instrumen baku yang berasal dari Instrumen Sertifikasi Dosen Penilaian Mahasiswa dari 4 (empat) kompetensi sebagai dasar dari aspek penilaian yakni pedagogik, profesional, kepribadian, dan sosial [18], maka peneliti hanya mengambil aspek penilaian kepribadian sebagai item pertanyaan untuk ditanyakan kepada mahasiswa. Analisis data dilakukan menggunakan analisis statistik sederhana persentase terhadap item butir pernyataan.

\section{HASIL DAN PEMBAHASAN}

Hasil analisis penelitian aspek kompetensi kepribadian adalah sebagai berikut.

TABEL I

ANALISIS ASPEK KOMPETENSI KEPRIBADIAN DOSEN PROGRAM STUDI BK FKIP ULM

\begin{tabular}{|c|c|c|c|c|c|c|c|}
\hline \multirow{2}{*}{ No } & \multirow{2}{*}{ Item Pernyataan } & \multicolumn{5}{|c|}{ Tingkat Pilihan } & \multirow{2}{*}{ Total } \\
\hline & & 1 & 2 & 3 & 4 & 5 & \\
\hline 1. & $\begin{array}{l}\text { Kewibawaan } \\
\text { sebagai pribadi }\end{array}$ & $6 \%$ & $10 \%$ & $2 \%$ & $31 \%$ & $51 \%$ & $100 \%$ \\
\hline 2. & $\begin{array}{l}\text { Kearifan dalam } \\
\text { mengambil }\end{array}$ & $6 \%$ & $10 \%$ & $4 \%$ & $32 \%$ & $48 \%$ & $100 \%$ \\
\hline 3. & $\begin{array}{l}\text { Menjadi contoh } \\
\text { dalam bersikap }\end{array}$ & $2 \%$ & $10 \%$ & $3 \%$ & $33 \%$ & $52 \%$ & $100 \%$ \\
\hline 4. & $\begin{array}{l}\text { Satunya kata dan } \\
\text { tindakan }\end{array}$ & $3 \%$ & $11 \%$ & $4 \%$ & $34 \%$ & $48 \%$ & $100 \%$ \\
\hline 5. & $\begin{array}{l}\text { Kemampuan } \\
\text { mengendalikan } \\
\text { diri dalam } \\
\text { berbagai situasi }\end{array}$ & $1 \%$ & $14 \%$ & $4 \%$ & $32 \%$ & $49 \%$ & $100 \%$ \\
\hline 6. & $\begin{array}{l}\text { Adil dalam } \\
\text { memperlakukan } \\
\text { mahasiswa }\end{array}$ & $6 \%$ & $8 \%$ & $3 \%$ & $33 \%$ & $50 \%$ & $100 \%$ \\
\hline
\end{tabular}

Keterangan

1: Sangat rendah

2: Rendah

3: Cukup

4: Tinggi

5: Sangat Tinggi

Secara berurutan berikut ini dikemukakan telaah temuan sesuai dengan 6 (enam) item pernyataan pada aspek kompetensi kepribadian dosen.

\section{A. Kewibawaan sebagai pribadi dosen}

Responden menyatakan bahwa kewibawaan sebagai pribadi dosen sangat tinggi tercatat sebanyak $51 \%$, sedangkan $31 \%$ menyatakan tinggi dan yang menyatakan cukup sebanyak $2 \%$. Responden yang berpandangan kewibawaan dosen yang 
dimaksud rendah dan sangat rendah masing-masing sebanyak $6 \%$ dan $10 \%$.

Hal dikarenakan kepribadian menentukan kewibawaan seorang guru dalam pandangan anak didik, sedangkan dosen juga dipandang sebagai guru ketika mereka berada dalam proses belajar dan pembelajaran [9].

\section{B. Kearifan dalam mengambil keputusan}

Sebanyak $48 \%$ responden mengakui bahwa dosen dianggap mampu dalam mengambil keputusan dengan sangat tinggi, 32\% diantaranya memandang tinggi. Dari kisaran tersebut $4 \%$ menilai cukup arif, $2 \%$ memandang rendah dan $1 \%$-nya sangat rendah. Kiranya hal ini dengan pandangan bahwa kepribadian seorang pendidik terlepas dari kemampuan mengambil keputusan secara arif [19]. Keputusan yang arif akan menunjang pembentukan karakter peserta didik, karena hakikat proses pendidikan juga tidak hanya berhubungan dengan transfer wawasan keilmuan [20].

\section{Menjadi contoh dalam bersikap dan berperilaku}

Item pernyataan ini mendapat respon yang tertinggi diantara 6 (enam) item pernyataan yang lain atau sebesar $52 \%$. Namun 33\%-nya memandang tinggi, dalam persentase cukup $3 \%$ dan rendah serta sangat rendah, masing-masing $10 \%$ dan $2 \%$.

Akar dari pandangan ini berlandaskan pada pandangan [21] dosen harus memiliki kriteria antusias, stimulatif, hangat, beroientasi pada tugas dan pekerja keras, toleran, bisa dipercaya dan sebagainya. Tentunya dapat dimafhumi sifatsifat baik dari seorang dosen sebagai pendidik akan menjadi contoh bersikap dan berperilaku [22].

Sebagaimana penelitian terhadap korelasi kompetensi kepribadian guru dan motivasi belajar siswa pada mata pelajaran PAI yang menunjukkan terdapat korelasi yang kuat [23].

\section{Satunya kata dan tindakan}

Hal ini mencerminkan pada konsistensi bersikap dan perilaku yang terefleksi pada keseharian seorang dosen. $48 \%$ responden menilai sangat tinggi dan 34\%-nya tinggi. Sementara itu, $4 \%$ hanya memandang cukup, $11 \%$ menilai rendah dan $3 \%$ sangat rendah. Penelitian mendalam terhadap dilematika profesi guru mengungkapkan keharusan guru mampu berkomunikasi dengan sesama guru, peserta didik dan masyarakat sekitar [24]. Dosen yang kurang memiliki kompetensi di bidangnya dapat mengganggu pencapaian sasaran akademik [25].

\section{E. Kemampuan mengendalikan diri dalam berbagai situasi dan kondisi}

Dari $49 \%$ responden mahasiswa menilai hal ini sangat tinggi dan $32 \%$ menilainya tinggi, meskipun demikian $4 \%$ menganggap cukup dan $14 \%$ menilai rendah. Hanya $1 \%$ saja melihatnya sangat rendah. Selaras dengan penelitian terhadap pengaruh sertifikasi dosen terhadap kinerja pengajaran dosen tidak terdapat perbedaan yang signifikan antara kinerja pedagogik sebelum dan setelah sertifikasi dosen [26]. Penelitian lain terhadap kompetensi dosen dan kondisi lingkungan berpengaruh terhadap motivasi belajar mahasiswa [27].

\section{F. Adil dalam memperlakukan mahasiswa}

Sekitar 50\% memiliki pandangan sangat tinggi bahwa dosen sudah adil memperlakukan mahasiswa dan 33\% melihatnya tinggi. Dari hal itu, yang berpandangan cukup hanya sebesar 3\% saja, berbanding dengan mereka yang menyatakan rendah sebesar $8 \%$ dan $6 \%$ sangat rendah. Realisasi kompetensi kepribadian cerminan dari kemampuan personal mencerminkan kepribadian yang mantap sehingga mampu menjadi teladan bagi peserta didik, dan berakhlak mulia [28]. Memperlukakan mahasiswa dengan baik dapat diungkapkan melalui mendidik dengan adab mulia [29].

\section{KESIMPULAN}

Dapat simpulkan bahwa aspek kompetensi kepribadian dosen Program Studi Bimbingan dan Konseling FKIP ULM pada item pernyataan, maka menjadi contoh dalam bersikap berperilaku menempati peringkat utama disusul dengan kewibawaan sebagai pribadi dan terakhir adil dalam memperlakukan mahasiswa. Meskipun tingkat pilihan yang berarti sangat rendah tidak besar, tetap saja perlu mendapat perhatian bersama yakni terutama pada poin kearifan dalam mengambil keputusan.

Saran terutama ditujukan kepada Fakultas Keguruan dan Ilmu Pendidikan agar dapat memperhatikan aspek kompetensi kepribadian diantara aspek-aspek yang lain. Meskipun perlu disadari bahwa aspek kepribadian sebagai suatu indikator yang mengukur kinerja dosen sangatlah subyektif atau tergantung pada selera pengalaman yang dirasakan oleh mahasiswa dalam berinteraksi dengan dosen bersangkutan. Secara implementatif praktis, pimpinan FKIP dapat mengembangkan program yang bertajuk pada harmonisasi antara dosen dan mahasiswa dengan sifat melekatkan kedua. Pengembangan pelatihana manajemen kepribadian dengan melibatkan unsur Pusat Layanan Bimbingan dan Konseling ULM juga bisa menjadi alternatif baik berupa workshop maupun pelatihan, mengingat interaksi mahasiswa dengan dosen dalam proses belajar dan pembelajaran hampir semuanya menyangkut pada aspek psikologis.

\section{DAFTAR PUSTAKA}

[1] Nomor, U. U. R. I. (14). Tahun 2005 tentang Guru dan Dosen.

[2] Dirjend. PI Kemenag. (2011). Petunjuk Teknis 'workshop' peningkatan kompetensi dosen Perguruan Tinggi Agama Islam. Direktorat Jenderal Pendidikan Islam Direktorat Pendidikan Tinggi Islam Kementerian Agama RI.

[3] Peraturan, P. (2009). Peraturan Pemerintah Republik Indonesia Nomor 37 Tahun 2009 Tentang Dosen.

[4] Taufiq, R. (2012). Penilaian Kinerja Dosen dalam Bidang BelajarMengajar di Fakultas Teknik Universitas Muhammadiyah Tangerang Faktor Exacta, 5(1), 77-85.

[5] Fathorrahman. (2017). Kompetensi Pedagogik, Profesional, Kepribadian dan Kompetensi Sosial Dosen. AKADEMIKA, 15(1), 1-6.

[6] Harisantoso J. (2012). Pengukuran Kinerja Dosen melalui EKD (Evaluasi Kinerja Dosen) STKIP PGRI Situbondo berdasarkan Persepsi Mahasiswa. Sainteks, 9(2), 64-71.

[7] Yulianingrum, K. (2014). Kompetensi Profesionalisme Guru Pendidikan Kewarganegaraan Ditinjau dari Latar Belakang Pendidikan 
(Studi Kasus Guru PKn di SMP Muhammadiyah 1 Surakarta). Skripsi Sarjana Fakultas Keguruan dan Ilmu Pendidikan, Universitas Muhammadiyah Surakarta: tidak diterbitkan.

[8] Yahya, Z., \& Hidayati, F. (2014). Analisis Kompetensi terhadap Penilaian Kinerja Dosen (Studi Kasus Dosen UIN Sultan Syarif Kasim Riau). Kutubkhanah: Jurnal Penelitian Sosial Keagamaan, 17(1), 104126.

[9] Fathiah, A., Ru'fah, A.N., \& Ulfa, K. (2017/208). Kompetensi Kepribadian. Makalah dalam Rangka Memenuhi Tugas Matakuliah Pengembangan Profesi Keguruan Program Studi Pendidikan Agama Islam Fakultas Tarbiyah Institut Ilmu Al-Qur'an Jakarta.

[10] Rozia, E. (2018). Kompetensi Kepribadian Guru dan Kontribusinya terhadap Pembentukan Akhlak Siswa pada Pembelajaran Tematik di Kelas 3 SD Islam Harapan Ibu. Skripsi Sarja Fakultas Ilmu Tarbiyah dan Keguruan, Universitas Islam Negeri Syarif Hidayatullah Jakarta: tidak diterbitkan.

[11] Ahmadi, R. (2016). Manajemen Pengembangan Kompetensi Dosen STAI Luqman Al Hakim Surabaya. Tesis Magister Program Pascasarjana Universitas Islam Negeri Sunan Kalijaga; tidak diterbitkan.

[12] Ayuning, T., \& Murni, M. (2018). Analisis Faktor-Faktor yang Mempengaruhi Kompetensi Dosen pada Politeknik LP3I Medan. Jurnal Konsep Bisnis dan Manajemen, 4(2), 120-131.

[13] S., Oktavianus S., Simanjuntak, V.G., \& Yunitaningrum, W. (2016) Survei Kompetensi Kepribadian dan Kompetensi Sosial Guru Pendidikan Jasmani Olahraga dan Kesehatan Sekolah Menengah Atas. Jurnal Pendidikan dan Pembelajaran, 5(10), 1-11.

[14] Multazam, M., Samsumar, L.D., \& Arwidiyarti, D. (2018). Rancang Bangun Sistem Informasi Evaluasi Kinerja Dosen dalam Perkuliahan untuk Meningkatkan Kualitas Proses Pembelajaran. Jurnal Teknologi Informasi dan Komunikasi, 7(2), 74-87.

[15] Siswanto, V.A., \& Wahjuningsih, T.P. (2015). Dampak Sertifikasi Dosen dan Motivasi terhadap Kinerja Dosen dengan Kepuasan sebagai Variabel Intervening di Perguruan Tinggi Kota Pekalongan. Makalah pada Prosiding Seminar Nasional Kebangkitan Teknologi, Kudus, 22 Agustus.

[16] Agung, I (2014). Kajian Pengaruh Kompetensi Kepribadian dan Sosial terhadap Kinerja Guru. Jurnal Ilmiah VISI P2TK PAUDNI, 9(2), 83-92.

[17] Haris, A. (2013). Pengaruh Kompetensi Pedagogik dan Kompetensi Kepribadian Terhadap Kinerja Dosen Fakultas Teknik. Skripsi Sarjana pada Fakultas Teknik, Universitas Negeri Semarang: tidak diterbitkan.

[18] Dirjend. PT Depdiknas. (2009). Lampiran P.I Instrumen Sertifikasi Dosen: Penilaian Mahasiswa, Direktorat Jenderal Pendidikan Tinggi Departemen Pendidikan Nasional.

[19] Sudjana, N. (2000). Dasar-dasar Proses Belajar-Mengajar. Bandung, Indonesia: Sinar Baru Algensindo.

[20] Soraya, N. (2018). Analisis Persepsi Mahasiswa terhadap Kompetens Dosen dalam Mengajar pada Program Studi Pai Fakultas Ilmu Tarbiyah dan Keguruan UIN Raden Fatah Palembang. Tadrib, 4(1), 183-204.

[21] Nento, S. (2012). Analisis Kompetensi Profesional dan Kinerja Dosen. Jurnal Ilmiah Iqra', 6(1), 1-17.

[22] Anwar, S. (2011). Studi Realitas Tentang Kompetensi Kepribadian Guru Pendidikan Agama Islam Sekolah Menengah Atas di Kabupaten Bandung Barat. Jurnal Pendidikan Agama Islam: Ta 'lim, 9(2), 145-159.

[23] Huda, M. (2017). Kompetensi Kepribadian Guru dan Motivasi Belajar Siswa (Studi Korelasi pada Mata Pelajaran PAI). Jurnal Penelitian, 11(2), 237-266.

[24] Dirhamsyah, F. (2008). Dilematika Profesi Guru: Studi tentang Undangundang Guru dan Dosen. Skripsi Sarjana Jurusan Pendidikan Agama Islam Fakultas Tarbiyah, Universitas Islam Negeri Malang: tidak diterbitkan.

[25] Murti, R.W., \& Prasetio, A.P. (2018). Pengaruh Kompetensi Dosen terhadap Prestasi Akademik Mahasiswa Fakultas Ekonomi dan Bisnis Telkom University. Jurnal Penelitian Pendidikan, 18(2), 94-102.

[26] Piscayanti, K.S., \& Mahayanti, N.W.S. (2015). Pengaruh Sertifikasi Dosen terhadap Kinerja Pengajaran Dosen UNDIKSHA. Jurnal Ilmu Sosial dan Humaniora, 4(1), 534-544.

[27] Martini \& Welas (tt). Analisis Kompetensi Dosen dan Kondisi Lingkungan dalam Upaya Meningkatkan Motivasi Belajar Mahasiswa. Makalah pada Portal Kopertis III (diakses pada: http://portal.kopertis3.or.id/handle/123456789/1566 [23 Agustus 2019]).
[28] Yamin, M. \& Maisah. (2010). Standarisasi Kinerja Guru. Jakarta, Indonesia: Gaung Persada.

[29] Fachrunnisa, M. (2016). Kompetensi Kepribadian Guru Menurut Pandangan An-Nawawi (Tela'ah Kitab At-Tibyan Fi Adabi Hamalah Al-Qur'an Karya Imam Abu Zakariya Yahya Bin Syaraf An-Nawawi) Skripsi Sarjana Fakultas Ilmu Tarbiyah dan Keguruan, Universitas Islam Negeri Maulana Malik Ibrahim: tidak diterbitkan. 